\title{
Proceeding
}

11th World Congress of Performance Analysis of Sport, 16-18 November 2016. International Society of Performance Analysis of Sport. Alicante, Spain

\section{Difference of the speed of handball throwing during the competition in relation to efficiency: Analysis between the first and the second half}

\author{
JUAN CARLOS ZAPARDIEL CORTÉS ${ }^{1}$ \\ ARTURO ABRALDES ${ }^{3}$, HELENA VILA ${ }^{4}$ \\ 1 University of Alcalá, Spain \\ 2University of Alicante, Spain \\ ${ }^{3}$ University of Murcia, Spain \\ 4 University of Vigo, Spain
} CARMEN FERRAGUT ${ }^{1}$, CARMEN MANCHADO², JOSÉ

\begin{abstract}
Throwing in handball is the most decisive action in success or failure in the offensive phases of the game. In order to study and analyse this, it is necessary to measure the throwing speed during the competition. This research aimed to achieve two objectives; the first one, to compare the average throwing speed between the first and the second half of the organized offensive phase during the 2013 Men's World Handball Championship. The second, to describe the throwing speed between the first and the second half during the 2013 Men's World Handball Championship with respect to its effectiveness (a goal/not a goal). Throwing speeds were registered in 47 matches in the 2013 World Handball Championship using a radar (StalkerPro S.A., Plano), with a frequency of $100 \mathrm{~Hz}$ and a sensitivity of $0.045 \mathrm{~m} / \mathrm{sec}-1$, fixed on a tripod behind the goal. Statistical analysis was carried out using SPSS software (version 22). The Kolgomorov-Smirnov test was used to check normality and homogeneity. The results show non-parametric variables. Subsequently, the variables were analysed with the Mann-Whitney U-test. Statistically significant differences were not found in the average throwing speed between the first and the second half of the matches of the World Championship, nor in its throwing effectiveness. These results show that fatigue is not a variable that influences the throwing
\end{abstract}

Corresponding author. University of Alcalá de Henares, Spain. http://orcid.org/0000-0002-1835-2085

E-mail: carlos.zapardiel@uah.es

11th World Congress of Performance Analysis of Sport, 16-18 November 2016. International Society of Performance Analysis of Sport. Alicante, Spain.

JOURNAL OF HUMAN SPORT \& EXERCISE ISSN 1988-5202

(c) Faculty of Education. University of Alicante

doi:10.14198/jhse.2017.12.Proc3.11

S872 | 2017 | Proc3 | VOLUME 12

(C) 2017 University of Alicante 
speeds along a handball match nor the precision/effectiveness in elite male handball. Key words: SHOT, MALE, GOAL, VELOCITY.

\section{Cite this article as:}

Zapardiel Cortés, J.C., Ferragut, C., Manchado, C., Abraldes, J.A. \& Vila, H. (2017). Difference of the speed of handball throwing during the competition in relation to efficiency: Analysis between the first and the second half. Journal of Human Sport and Exercise, 12(3proc), S872-S881. doi:https://doi.org/10.14198/ihse.2017.12.Proc3.11 


\section{INTRODUCTION}

Throwing is a decisive ability in the victory of a handball match. For that reason, the number of researches centered on the throwing speed in handball has increased during the last years (Hermassi et al., 2015; Raeder et al., 2016), but the studies focus on analysing the speeds registered in training situations (AguilarMartínez et al., 2012; Hermassi et al., 2015; Van den Tillaar \& Marques, 2011). In some cases, the existing possible relations between throwing speed and the anthropometric variables were studied (Debanne \& Laffaye, 2011; Vila et al., 2009); in other cases, biomechanical analyses of the throwing speed in handball players were carried out (Van den Tillaar et al., 2013; Wagner et al., 2014; Wagner et al., 2010; Wagner et al., 2011). Also, the possibility of relations between the development of conditional capabilities and the throwing speed in handball has been studied (Granados et al., 2013; Sabido et al., 2016; Van den Tillaar, 2004); or whether the opposing actions can modify the throwing speed (Rivilla et al., 2010a; Rivilla, et al, 2010b).

One of the conclusions extracted from the analysed studies is that two of the main factors that determine the throwing in handball are speed itself and execution accuracy (García et al., 2013; Gorostiaga et al., 1999; Van den Tillaar, 2003; Van den Tillaar \& Ettema, 2003; Wagner et al., 2011). The relation between throwing speed and execution accuracy is inversely proportional, that is why there are studies that aim at improving throwing accuracy without reducing the speed (García et al., 2013). If a subject manages to reach maximum speed of execution during the carrying out of a throwing, variability and percentage error increases; however, facing submaximum throwings, variability and percentage error decrease (Etnyre, 1998). It is necessary to keep in mind that throwings are carried out without the opposition of the goalkeeper in the study of Etnyre (1998). Goalkeepers are determinant for throwing efficacy in sports such as handball (Pascual et al., 2010). Therefore, in the relation accuracy-speed, the goalkeeper should also be included as an external factor which makes the execution speed of throwings change (Rivilla et al., 2010).

In the extensive existing bibliography about the analysis of throwing in handball, registers of throwing speed during the competition have not been found. This analysis focuses on the study of throwing efficacy (Dulgheru, 2012; Ferrari et al., 2014; Gutiérrez-Dávila et al., 2011). There exist no values of the throwing speeds during the competition. Neither there are studies during competitions about the relation throwing speed and effectiveness. These data are relevant for the coach, as they allow him to focus his training sessions, both for performance and tactics.

In order to study and analyse this, it is necessary to measure the throwing speed during the competition. This research aimed to achieve two objectives; the first one, to compare the average throwing speed between the first and the second half of the organized offensive phase during the 2013 Men's World Handball Championship. The second, to describe the throwing speed between the first and the second half during the 2013 Men's World Handball Championship with respect to its efficacy (a goal/not a goal).

\section{MATERIALS AND METHODOLOGY}

\section{Measures and procedures}

During the 2013 Men's World Handball Championship held in Spain, ball speed from 3214 throws out of the 5015 analysed ones were registered. To that effect, 47 out of the 76 matches played during the championship were observed: 31 during the group stage, 8 during the qualifying round of 16, 4 in the quarter-finals, and 4 in the semi-finals and final. 
In situ, two qualified observers per match gathered twelve variables regarding throwing using an observation tool (Figure 1). These variables were: playing time, first or second half, player who carries out the throw, zone of the playing field from where the shot is performed, distance, type, trajectory, opposition, contact, effectiveness, accuracy, and attack phase. All the observers had brought the variables together and practiced data collection in the four weeks preceding the championship matches.
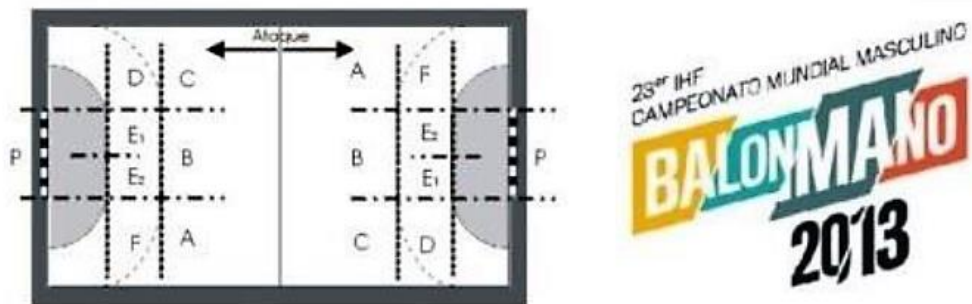

Equipo:

RIval:

Nivel:



E. Anallzado: Grabaclón: Resultado:

\begin{tabular}{|c|c|c|c|c|c|c|c|c|c|c|c|c|c|}
\hline Tlempo & Parte & Jugador & Zona & Dist. & Lanz. & Tray. & Oposición & Contacto & Velocidad & Fin & Prec. & Jugada \\
\hline$\vdots$ & & & & & & & & & & & & \\
\hline$\vdots$ & & & & & & & & & & & & \\
\hline$\vdots$ & & & & & & & & & & & & & \\
\hline$\vdots$ & & & & & & & & & & & & \\
\hline$\vdots$ & & & & & & & & & & & & \\
\hline
\end{tabular}

Figure 1. Observation sheet

At the same time, throwing velocity was assessed using a radar gun (StalkerPro Inc., Plano, TX, USA) with $100 \mathrm{~Hz}$ recording frequency and $0.045 \mathrm{~m} / \mathrm{sec}^{-1}$ sensitivity, placed behind the goal post in a direction perpendicular to the player. The radar was placed behind the goal at a distance of 3 metres and a height of 1.20 metres. Two observers carried out this task. One of them registered throwing speed; the other one registered the player who executed the throw.

Once the championship ended, the analysed matches were downloaded and they were viewed again in order to correct the possible mistakes that may have arised while registering data in situ. LINCE software was used for the register of the observed actions (Gabín, 2011); it was developed by the research team of the Laboratori d'Observació de la Motricitat from INEF in Lleida. This software package is developed in Java, making it compatible with multiple platforms. It has been designed to observe any type of event and allows to carry out systems designs, video registers and data quality controls, and also to export results in different formats (Lozano, 2014). Another advantage of this software is the ease to create new register panels based on a basic register panel. 


\section{Analysis}

The reliability of the observation of the matches assessing the intraobserver concordance was studied using Cohen's Kappa index (Cohen, 1960). The interpretation of the agreement degree proposed by Landis y Koch (1977) was valued as very good.

The collected data were codified and registered on an Excel data entry form. Afterwards, the data were filtered.

Statistical analysis was carried out using SPSS software (version 22). A descriptive analysis of the variables speed, first or second half, and effectiveness of each of the teams analysed. The Kolgomorov-Smirnov test was used to check normality and homogeneity. The results show non-parametric variables. Subsequently, the variables were analysed with the Mann-Whitney U-test. The $p \leq 0.05$ criterion was used for establishing statistical significance.

\section{RESULTS}

Out of the 20 observed teams (Table 1), the medium-speed range in the first half is between $25.14 \mathrm{~m} / \mathrm{sec}^{-1}$ from Poland and $21.06 \mathrm{~m} / \mathrm{sec}^{-1}$ from Algeria, while the speed range in the second half is between 24.28 $\mathrm{m} / \mathrm{sec}^{-1}$ from Denmark and $20.92 \mathrm{~m} / \mathrm{sec}^{-1}$ from Montenegro. The national teams placed in the first positions present medium-speed ranges superior to $22.11 \mathrm{~m} / \mathrm{sec}^{-1}$, with the exception of Slovenia in the first half and France in the second half. Out of the 20 observed teams, 11 presented a medium speed superior in the second half $(p<0.05)$. Regarding the throws that did not become a goal, greater medium speed in the throws of 13 national teams in the first half and of 9 in the second half was registered $(p<0.05)$. 
Table 1. Throwing medium speed $\left(\mathrm{m} / \mathrm{sec}^{-1}\right)$ by the different national teams taking part in the 2013 Men's World Handball Championship

\begin{tabular}{|c|c|c|c|c|c|c|c|c|c|c|}
\hline & \multicolumn{5}{|c|}{ FIRST HALF } & \multicolumn{5}{|c|}{ SECOND HALF } \\
\hline Team/n & Total & $\begin{array}{l}\text { Not } \\
\text { Goal }\end{array}$ & Order & Goal & Order & Total & $\begin{array}{c}\text { Not } \\
\text { Goal }\end{array}$ & Order & Goal & Order \\
\hline $\begin{array}{c}\text { Spain } \\
374\end{array}$ & $\begin{array}{l}22,27 \\
\pm 4,47\end{array}$ & $\begin{array}{l}22,50 \\
\pm 4,69\end{array}$ & 9 & $\begin{array}{l}22,04 \\
\pm 4,30\end{array}$ & 9 & $\begin{array}{l}22,43 \\
\pm 4,46\end{array}$ & $\begin{array}{l}21,88 \\
\pm 4,52\end{array}$ & 13 & $\begin{array}{l}22,98 \\
\pm 4,37\end{array}$ & 6 \\
\hline $\begin{array}{c}\text { Denmark } \\
160\end{array}$ & $\begin{array}{l}22,22 \\
\pm 4,83 \\
\end{array}$ & $\begin{array}{l}24,00 \\
\pm 4,70 \\
\end{array}$ & 2 & $\begin{array}{l}20,43 \\
\pm 4,51 \\
\end{array}$ & 20 & $\begin{array}{l}24,28 \\
\pm 3,94 \\
\end{array}$ & $\begin{array}{l}24,15 \\
\pm 4,17 \\
\end{array}$ & 3 & $\begin{array}{l}24,40 \\
\pm 3,74 \\
\end{array}$ & 2 \\
\hline $\begin{array}{c}\text { Croatia } \\
361\end{array}$ & $\begin{array}{l}22,52 \\
\pm 4,61\end{array}$ & $\begin{array}{l}22,71 \\
\pm 4,61\end{array}$ & 6 & $\begin{array}{l}22,33 \\
\pm 4,62\end{array}$ & 8 & $\begin{array}{l}22,12 \\
\pm 4,33\end{array}$ & $\begin{array}{l}21,55 \\
\pm 4,61\end{array}$ & 19 & $\begin{array}{l}22,70 \\
\pm 4,04\end{array}$ & 9 \\
\hline $\begin{array}{c}\text { Slovenia } \\
144\end{array}$ & $\begin{array}{l}21,26 \\
\pm 4,08\end{array}$ & $\begin{array}{l}21,77 \\
\pm 4,42\end{array}$ & 15 & $\begin{array}{l}20,75 \\
\pm 3,82\end{array}$ & 19 & $\begin{array}{l}23,37 \\
\pm 3,94\end{array}$ & $\begin{array}{l}23,78 \\
\pm 3,80\end{array}$ & 4 & $\begin{array}{l}22,97 \\
\pm 4,04\end{array}$ & 7 \\
\hline $\begin{array}{c}\text { Germany } \\
224\end{array}$ & $\begin{array}{l}23,23 \\
\pm 4,03 \\
\end{array}$ & $\begin{array}{l}23,49 \\
\pm 4,01 \\
\end{array}$ & 4 & $\begin{array}{l}22,97 \\
\pm 4,07 \\
\end{array}$ & 5 & $\begin{array}{l}23,03 \\
\pm 4,11 \\
\end{array}$ & $\begin{array}{l}23,02 \\
\pm 4,11 \\
\end{array}$ & 5 & $\begin{array}{l}23,04 \\
\pm 4,14 \\
\end{array}$ & 5 \\
\hline $\begin{array}{c}\text { France } \\
229 \\
\end{array}$ & $\begin{array}{l}23,79 \\
\pm 3,83 \\
\end{array}$ & $\begin{array}{l}24,00 \\
\pm 4,21 \\
\end{array}$ & 3 & $\begin{array}{l}23,58 \\
\pm 3,64\end{array}$ & 4 & $\begin{array}{l}21,40 \\
\pm 4,22 \\
\end{array}$ & $\begin{array}{l}22,11 \\
\pm 4,21 \\
\end{array}$ & 11 & $\begin{array}{l}20,71 \\
\pm 4,17 \\
\end{array}$ & 18 \\
\hline $\begin{array}{c}\text { Russia } \\
50\end{array}$ & $\begin{array}{l}23,08 \\
\pm 3,88\end{array}$ & $\begin{array}{l}22,34 \\
\pm 4,36\end{array}$ & 10 & $\begin{array}{l}23,82 \\
\pm 3,43\end{array}$ & 3 & $\begin{array}{l}23,42 \\
\pm 4,97\end{array}$ & $\begin{array}{l}22,30 \\
\pm 7,25\end{array}$ & 8 & $\begin{array}{l}24,55 \\
\pm 3,11\end{array}$ & $I$ \\
\hline $\begin{array}{c}\text { Hungary } \\
263\end{array}$ & $\begin{array}{l}22,57 \\
\pm 4,86\end{array}$ & $\begin{array}{l}22,30 \\
\pm 5,06\end{array}$ & 11 & $\begin{array}{l}22,84 \\
\pm 4,71\end{array}$ & 6 & $\begin{array}{l}22,40 \\
\pm 4,22\end{array}$ & $\begin{array}{l}22,58 \\
\pm 4,41\end{array}$ & 7 & $\begin{array}{l}22,22 \\
\pm 4,11\end{array}$ & 12 \\
\hline $\begin{array}{c}\text { Poland } \\
36\end{array}$ & $\begin{array}{l}25,14 \\
\pm 3,23\end{array}$ & $\begin{array}{l}26,39 \\
\pm 1,58\end{array}$ & $I$ & $\begin{array}{l}23,89 \\
\pm 4,03\end{array}$ & 2 & $\begin{array}{l}23,29 \\
\pm 3,96\end{array}$ & $\begin{array}{l}25,58 \\
\pm 2,47\end{array}$ & 1 & $\begin{array}{l}21,01 \\
\pm 4,31\end{array}$ & 17 \\
\hline $\begin{array}{c}\text { Serbia } \\
38\end{array}$ & $\begin{array}{l}23,22 \\
\pm 4,20\end{array}$ & $\begin{array}{l}22,23 \\
\pm 4,73\end{array}$ & 13 & $\begin{array}{l}24,21 \\
\pm 3,77\end{array}$ & 1 & $\begin{array}{l}21,27 \\
\pm 4,23\end{array}$ & $\begin{array}{l}20,07 \\
\pm 4,43\end{array}$ & 20 & $\begin{array}{l}22,46 \\
\pm 3,41\end{array}$ & 11 \\
\hline $\begin{array}{c}\text { Tunisia } \\
171\end{array}$ & $\begin{array}{l}21,77 \\
\pm 4,13\end{array}$ & $\begin{array}{l}21,97 \\
\pm 3,99\end{array}$ & 14 & $\begin{array}{l}21,57 \\
\pm 4,30\end{array}$ & 11 & $\begin{array}{l}22,74 \\
\pm 4,30\end{array}$ & $\begin{array}{l}22,64 \\
\pm 4,74\end{array}$ & 6 & $\begin{array}{l}22,82 \\
\pm 4,03\end{array}$ & 8 \\
\hline $\begin{array}{c}\text { Iceland } \\
41\end{array}$ & $\begin{array}{l}21,22 \\
\pm 3,67 \\
\end{array}$ & $\begin{array}{l}21,42 \\
\pm 3,91\end{array}$ & 18 & $\begin{array}{l}21,01 \\
\pm 3,67\end{array}$ & 15 & $\begin{array}{l}23,94 \\
\pm 2,95\end{array}$ & $\begin{array}{l}24,48 \\
\pm 2,35\end{array}$ & 2 & $\begin{array}{l}23,41 \\
\pm 3,27\end{array}$ & 4 \\
\hline $\begin{array}{c}\text { Brazil } \\
181 \\
\end{array}$ & $\begin{array}{l}21,59 \\
\pm 3,79 \\
\end{array}$ & $\begin{array}{l}21,62 \\
\pm 3,81 \\
\end{array}$ & 16 & $\begin{array}{l}21,56 \\
\pm 3,81 \\
\end{array}$ & 12 & $\begin{array}{l}21,50 \\
\pm 3,45 \\
\end{array}$ & $\begin{array}{l}21,55 \\
\pm 3,43 \\
\end{array}$ & 18 & $\begin{array}{l}21,45 \\
\pm 3,58 \\
\end{array}$ & 18 \\
\hline $\begin{array}{c}\text { Macedonia } \\
37\end{array}$ & $\begin{array}{l}22,97 \\
\pm 4,59\end{array}$ & $\begin{array}{l}22,71 \\
\pm 3,85\end{array}$ & 7 & $\begin{array}{l}23,24 \\
\pm 4,41\end{array}$ & 13 & $\begin{array}{l}22,83 \\
\pm 3,79\end{array}$ & $\begin{array}{l}22,04 \\
\pm 3,16\end{array}$ & 12 & $\begin{array}{l}23,63 \\
\pm 3,65\end{array}$ & 3 \\
\hline $\begin{array}{c}\text { Belarus } \\
39\end{array}$ & $\begin{array}{l}21,93 \\
\pm 4,27\end{array}$ & $\begin{array}{l}22,98 \\
\pm 3,98\end{array}$ & 5 & $\begin{array}{l}20,98 \\
\pm 4,65\end{array}$ & 16 & $\begin{array}{l}22,09 \\
\pm 3,57\end{array}$ & $\begin{array}{l}22,22 \\
\pm 3,53\end{array}$ & 9 & $\begin{array}{l}21,97 \\
\pm 3,77\end{array}$ & 14 \\
\hline $\begin{array}{l}\text { Egypt } \\
222\end{array}$ & $\begin{array}{l}21,71 \\
\pm 4,08\end{array}$ & $\begin{array}{l}22,60 \\
\pm 4,14\end{array}$ & 8 & $\begin{array}{l}20,82 \\
\pm 3,89\end{array}$ & 17 & $\begin{array}{l}22,35 \\
\pm 4,27\end{array}$ & $\begin{array}{l}21,84 \\
\pm 4,73\end{array}$ & 15 & $\begin{array}{l}22,57 \\
\pm 3,80\end{array}$ & 10 \\
\hline $\begin{array}{c}\text { Algeria } \\
171\end{array}$ & $\begin{array}{l}21,06 \\
\pm 4,36 \\
\end{array}$ & $\begin{array}{l}21,32 \\
\pm 4,52 \\
\end{array}$ & 20 & $\begin{array}{l}20,81 \\
\pm 4,19 \\
\end{array}$ & 18 & $\begin{array}{l}22,03 \\
\pm 4,30 \\
\end{array}$ & $\begin{array}{l}22,15 \\
\pm 4,70 \\
\end{array}$ & 10 & $\begin{array}{l}21,91 \\
\pm 4,05 \\
\end{array}$ & 15 \\
\hline $\begin{array}{c}\text { Argentina } \\
149\end{array}$ & $\begin{array}{l}22,35 \\
\pm 4,05\end{array}$ & $\begin{array}{l}22,29 \\
\pm 4,08\end{array}$ & 12 & $\begin{array}{l}22,41 \\
\pm 4,07\end{array}$ & 7 & $\begin{array}{l}21,94 \\
\pm 3,93\end{array}$ & $\begin{array}{l}21,87 \\
\pm 4,23\end{array}$ & 14 & $\begin{array}{l}22,01 \\
\pm 3,76\end{array}$ & 13 \\
\hline $\begin{array}{c}\text { Montenegro } \\
160\end{array}$ & $\begin{array}{l}21,47 \\
\pm 4,13\end{array}$ & $\begin{array}{l}21,40 \\
\pm 4,88\end{array}$ & 19 & $\begin{array}{l}21,53 \\
\pm 5,01\end{array}$ & 14 & $\begin{array}{l}20,92 \\
\pm 3,50\end{array}$ & $\begin{array}{l}21,82 \\
\pm 3,19\end{array}$ & 16 & $\begin{array}{l}20,02 \\
\pm 4,08\end{array}$ & 20 \\
\hline $\begin{array}{c}\text { Australia } \\
164\end{array}$ & $\begin{array}{l}21,54 \\
\pm 3,79\end{array}$ & $\begin{array}{l}21,43 \\
\pm 3,76\end{array}$ & 17 & $\begin{array}{l}21,64 \\
\pm 3,97\end{array}$ & 10 & $\begin{array}{l}21,16 \\
\pm 3,76\end{array}$ & $\begin{array}{l}21,70 \\
\pm 3,73\end{array}$ & 17 & $\begin{array}{l}20,63 \\
\pm 3,59\end{array}$ & 19 \\
\hline
\end{tabular}

The medium speed registered in the total number of throws during the 2013 Men's World Handball Championship (Table 2) in the first and the second halves of the match, as well as the speed of the throws that became a goal and those that did not, showed a value of $22 \mathrm{~m} / \mathrm{sec}^{-1}$. Statistical differences between the throws in the first and the second half were not registered. 
Table 2. Medium speed and standard deviation of the throws during the 2013 Men's World Handball Championship

\begin{tabular}{|c|c|c|c|c|c|c|}
\hline & \multicolumn{3}{|c|}{ First half $(\mathrm{n}=1588)$} & \multicolumn{3}{c|}{ Second half $(\mathrm{n}=1626)$} \\
\hline & Total & $\begin{array}{c}\text { Not Goal } \\
(\mathrm{n}=743)\end{array}$ & $\begin{array}{c}\text { Goal } \\
(\mathrm{n}=845)\end{array}$ & Total & $\begin{array}{c}\text { Goal } \\
(\mathrm{n}=920)\end{array}$ & $\begin{array}{c}\text { Not Goal } \\
(\mathrm{n}=706)\end{array}$ \\
\hline $\begin{array}{c}\text { Speed } \\
\left(\mathrm{m} / \mathrm{sec}^{-1}\right)\end{array}$ & $22.23 \pm 4.31$ & $22,42 \pm 4.37$ & $22,07 \pm 4.26$ & $22.30 \pm 4.18$ & $22,32 \pm 4.08$ & $22,28 \pm 4.31$ \\
\hline
\end{tabular}

\section{DISCUSSION}

Throwing speed is not influenced by the duration of the match. These studies are in line with the study by (Andrade et al., 2016; Plummer \& Oliver, 2016). In the total number of analysed throws there are no statistical differences between throwing speed when there is a goal and when there is not. The registered speeds cannot be compared to previous studies, but it is important for coaches to know the medium speeds from the best teams in the world and use them as a reference to plan their training sessions. Several studies analyse throwing speed during the training session and in different situations (mainly with no opposition). In 7-metre throws, speeds between 19.3 and $20.0 \mathrm{~m} / \mathrm{sec}^{-1}$ have been registered; in 9-metre standing throws without runup, speeds ranged between 23.8 and $25.6 \mathrm{~m} / \mathrm{sec}^{-1}$, and from 23.0 to $23.1 \mathrm{~m} / \mathrm{sec}^{-1}$ in in jump throws (Gorostiaga et al., 2005; Hermassi et al., 2015; Marques et al., 2007; Rivilla et al., 2011; Rousanoglou et al., 2015). In the event we wish to carry out some comparison of the registered speeds in this study with those presented in other researches, some considerations should be taken into account. The number of throws registered and analysed in our study is much higher than those set out in the situations described by the other studies. Our study showed that there is no standard recovery time to guarantee that fatigue does not influence in throwing speed. Taking into account that we are dealing with real play situations, we must emphasise that there exists the presence of opposition (goalkeeper and defence) in the throwing situation at all times. Finally, we have to make known the existing differences between the studies regarding working methodology. Among others, it should be pointed out that the register tools were different (on some occasions, radars were used; on other occasions, video cameras) and that the position of the measuring tools changed (perpendicular or parallel to the throw). On the contrary, all the studies coincide that elite handball players are able to generate similar speeds.

In a descriptive analysis between the medium speeds registered by the different national teams observed, it is noticed that the teams placed in the first positions in the Championship present medium speeds superior to $22 \mathrm{~m} / \mathrm{sec}^{-1}$ and reach medium values of $23 \mathrm{~m} / \mathrm{sec}^{-1}$, while those teams placed in the last positions of the classification have not registered medium speeds superior to $22 \mathrm{~m} / \mathrm{sec}^{-1}$ in all the throws in both halves of the match. It cannot be stated that speed differentiates between throws that become goals and those that do not. However, if the behaviour of the five top-ranked teams is analysed, it can be proved that the medium speeds of the throws that became goals are higher in the second half of the match, being even the medium speeds higher than the throws that did not become a goal in the case of four national teams (Spain, Denmark, Croatia and Germany). This behaviour was not registered in the first half, when the medium speeds were higher in no-goal situations. These data suggest that the players are able to throw with great speed at any time during the match, but the effectiveness in the second hand can only be achieved with higher speeds. Studies regarding throwing accuracy and speed in handball present contradictory results. In this research, the results are in line with the study of Zapartidis et al. (2007), carried out with female handball players. We point out that there exist multiple throw situations; and in this study the recorded throws in the frontal part of the goal (central and lateral area) and at different distances are presented. 


\section{CONCLUSIONS}

Medium speed of the throw in handball players is not influenced by the duration of the match.

There are no differences in the medium speed of throws between those that become a goal and those that do not.

The medium-speed range for elite handball fluctuates between 22 and $23 \mathrm{~m} / \mathrm{sec}-1$.(Rousanoglou et al., 2015).

The experiments comply with the current laws of Spain.

\section{REFERENCES}

1. Aguilar-Martínez, D., Chirosa, L. J., Martín, I., Chirosa, I. J., \& Cuadrado-Reyes, J. (2012). Efecto del entrenamiento de la potencia sobre la velocidad de lanzamiento en balonmano. Revista Internacional De Medicina Y Ciencias De La Actividad Física Y Del Deporte, (48), 729-744.

2. Andrade, M. S., de Carvalho Koffes, F., Benedito-Silva, A. A., da Silva, A. C., \& de Lira, C. A. B. (2016). Effect of fatigue caused by a simulated handball game on ball throwing velocity, shoulder muscle strength and balance ratio: A prospective study. BMC Sports Science, Medicine and Rehabilitation, 8(1), 1-7. https://doi.org/10.1186/s13102-016-0038-9

3. Cohen, J. (1960). A coefficient of agreement for nominal scales. Educational and Psychosocial Measurement, 20, 37-46. https://doi.org/10.1177/001316446002000104

4. Debanne, T., \& Laffaye, G. (2011). Predicting the throwing velocity of the ball in handball with anthropometric variables and isotonic tests. Journal of Sports Sciences, 29(7), 705-713. https://doi.org/10.1080/02640414.2011.552112

5. Dulgheru, M. (2012). The efficiency of the goal procedures at the level of women handball teams seniors. Ovidius University Annals, Series Physical Education \& Sport/Science, Movement \& Health, 12(2), 319-325.

6. Etnyre, B. R. (1998). Accuracy characteristics of throwing as a result of maximum force effort. Perceptual and Motor Skills, 86(3 suppl), 1211-1217. https://doi.org/10.2466/pms.1998.86.3c.1211

7. Ferrari, W. R., dos Santos, J. V., \& Simões Vaz, V. P. (2014). Offensive process analysis in handball: Identification of game actions that differentiate winning from losing teams. American Journal of Sports Science, 2(4), 92-96. https://doi.org/10.11648/iajss.20140204.14

8. Gabín Moreira, B. (2011). Lince, automatización de datos observacionales para "Avances tecnológicos y metodológicos en la automatización de estudios observacionales en deporte". Unpublished manuscript.

9. García, J. A., Sabido, R., Barbado, D., \& Moreno, F. J. (2013). Analysis of the relation between throwing speed and throwing accuracy in team-handball according to instruction. European Journal of Sport Science, 13(2), 149-154. https://doi.org/10.1080/17461391.2011.606835

10. Gorostiaga, E., Granados, C., Ibanez, J., \& Izquierdo, M. (2005). Differences in physical fitness and throwing velocity among elite and amateur male handball players. International Journal of Sports Medicine, 26(03), 225-232. https://doi.org/10.1055/s-2004-820974

11. Gorostiaga, E. M., Izquierdo, M., Iturralde, P., Ruesta, M., \& Ibá-ez, J. (1999). Effects of heavy resistance training on maximal and explosive force production, endurance and serum hormones in adolescent handball players. European Journal of Applied Physiology and Occupational Physiology, 80(5), 485-493. https://doi.org/10.1007/s004210050622 
12. Granados, C., Izquierdo, M., Ibanez, J., Ruesta, M., \& Gorostiaga, E. M. (2013). Are there any differences in physical fitness and throwing velocity between national and international elite female handball players? Journal of Strength and Conditioning Research / National Strength \& Conditioning Association, 27(3), 723-732.

13. Gutiérrez-Dávila, M., Ortega, M., Montilla, J. A. P., Campos, J., \& Ruiz, F. J. R. (2011). Variabilidad de la secuencia temporal de la cadena cinética en el lanzamiento de balonmano. Revista Internacional De Medicina Y Ciencias De La Actividad Física Y Del Deporte, (43), 2-2.

14. Hermassi, S., van den Tillaar, R., Khlifa, R., Chelly, M. S., \& Chamari, K. (2015). Comparison of inseason-specific resistance vs. a regular throwing training program on throwing velocity, anthropometry, and power performance in elite handball players. Journal of Strength and Conditioning Research / National Strength \& Conditioning Association, 29(8), 2105-2114. https://doi.org/10.1519/JSC.0000000000000855

15. Landis, J. R., \& Koch, G. G. (1977). The measurement of observer agreement for categorical data. Biometrics, 33(1), 159-174. https://doi.org/10.2307/2529310

16. Lozano, D. (2014). Análisis del comportamiento táctico ofensivo en alto rendimiento en balonmano (Doctoral thesis).

17. Marques, M. C., Van den Tillaar, R., Vescovi, J. D., \& González-Badillo, J. J. (2007). Relationship between throwing velocity, muscle power, and bar velocity during bench press in elite handball players. International Journal of Sports Physiology and Performance, 2(4), 414. https://doi.org/10.1123/ijspp.2.4.414

18. Pascual, X., Lago, C., \& Casáis, L. (2010). La influencia de la eficacia del portero en el rendimiento de los equipos de balonmano. Apunts. Educación Física Y Deportes, (99), 72-81.

19. Plummer, H. A., \& Oliver, G. D. (2017). The effects of localised fatigue on upper extremity jump shot kinematics and kinetics in team handball. Journal of Sports Sciences, 35(2), 182-188. http://doi.org/10.1080/02640414.2016.1160143

20. Raeder, C., Fernandez-Fernandez, J., \& Ferrauti, A. (2015). Effects of six weeks of medicine ball training on throwing velocity, throwing precision, and isokinetic strength of shoulder rotators in female handball players. Journal of Strength and Conditioning Research / National Strength \& Conditioning Association, 29(7), 1904-1914. https://doi.org/10.1519/JSC.0000000000000847

21. Rivilla, J., Martínez, I., Grande, I., \& Sampedro, J. (2011). Relation between general throwing tests with a medicine ball and specific tests to evaluate throwing velocity with and without opposition in handball. Journal of Human Sport \& Exercise, 6(2), 414-426. https://doi.org/10.4100/ihse.2011.62.22

22. Rivilla, J., Sampedro, J., Navarro, F., \& Gómez, M. (2010a). Influence of the opposition in throwing velocity in elite, amateur and formative handball players. Int J Sport Sci, 18(6), 91-99.

23. Rivilla, J., Martín, I. M., Valdivielso, F. N., \& Molinuevo, J. S. (2010b). Differences in the throwing distance and ball velocity by playing position in under-18 handball players. RICYDE. Revista Internacional De Ciencias Del Deporte., 7(22), 14-23. https://doi.org/10.5232/ricyde2011.02202

24. Rousanoglou, E. N., Noutsos, K. S., Bayios, I. A., \& Boudolos, K. D. (2015). Self-Paced and Temporally Constrained Throwing Performance by Team-Handball Experts and Novices without Foreknowledge of Target Position. Journal of Sports Science \& Medicine, 14(1), 41-46.

25. Sabido, R., Hernández-Davó, J. L., Botella, J., \& Moya, M. (2016). Effects of 4-week training intervention with unknown loads on power output performance and throwing velocity in junior team handball players. PloS One, 11(6), 1-12. https://doi.org/10.1371/journal.pone.0157648

26. Serrien, B., Clijsen, R., Anders, S., Goossens, M., \& Baeyens, J. (2016). Intra-seasonal variability of ball speed and coordination of two team-handball throwing techniques in elite male adolescent players. International Journal of Computer Science in Sport, 15(1), 1-21. https://doi.org/10.1515/ijcss-2016-0001 
27. Van den Tillaar, R. (2004). Effect of different training programs on the velocity of overarm throwing: A brief review. Journal of Strength and Conditioning Research / National Strength \& Conditioning Association, 18(2), 388-396. https://doi.org/10.1519/00124278-200405000-00033

28. Van den Tillaar, R., Zondag, A., \& Cabri, J. (2013). Comparing performance and kinematics of throwing with a circular and whip-like wind up by experienced handball players. Scandinavian Journal of Medicine \& Science in Sports, 23(6), e373-e380. https://doi.org/10.1111/sms.12091

29. Van den Tillaar, R. (2003). Effect of different constraints on coordination and performance in overarm throwing. Fakultet for samfunnsvitenskap og teknologiledelse.

30. Van den Tillaar, R., \& Marques, M. (2011). Effect of training on ball release velocity and kinematics in overarm throwing among experienced female handball players. Kinesiologia Slovenica, 17(2), 3846.

31. Van den Tillaar, R., \& Ettema, G. (2003). Instructions emphasizing velocity, accuracy, or both in performance and kinematics of overarm throwing by experienced team handball players. Perceptual and Motor Skills, 97(3 Pt 1), 731-742. https://doi.org/10.2466/pms.2003.97.3.731

32. Vila, H., Alcaraz, P., Ferragut, C., Rodríguez, N., \& Cruz, M. (2009). Perfil cineantropométrico, composición corporal y condición física en jugadoras de balonmano de nivel nacional. Apunts : Educación Física Y Deportes, (98), 46-50.

33. Wagner, H., Buchecker, M., von Duvillard, S. P., \& Müller, E. (2010). Kinematic Description of Elite Vs. Low Level Players in Team-Handball Jump Throw. Journal of Sports Science \& Medicine, 9(1), 15-23.

34. Wagner, H., Pfusterschmied, J., von Duvillard, S. P., \& Müller, E. (2011). Performance and Kinematics of Various Throwing Techniques in Team-Handball. Journal of Sports Science \& Medicine, 10(1), 73-80.

35. Wagner, H., Pfusterschmied, J., Tilp, M., Landlinger, J., Von Duvillard, S., \& Müller, E. (2014). Upperbody kinematics in team-handball throw, tennis serve, and volleyball spike. Scandinavian Journal of Medicine \& Science in Sports, 24(2), 345-354. https://doi.org/10.1111//.1600-0838.2012.01503.X

36. Zapartidis, I., Gouvali, M., Bayios, I., \& Boudolos, K. (2007). Throwing effectiveness and rotational strength of the shoulder in team handball. The Journal of Sports Medicine and Physical Fitness, 47(2), 169-178. 